\title{
VALUES SUPPORTING THE SUSTAINABILITY OF INCLUSIVE EDUCATION IN DIFFERENT PRACTICES
}

\author{
Alvyra Galkienè \\ Vytautas Magnus University, Lithuania
}

\begin{abstract}
This article analyses how fundamental values underpin educational practices that have emerged in the development of society and create the preconditions for the sustainability of inclusive education. Through the analysis of the scholarly literature, the expression of inclusive values in the application of approaches to integrated, individualised inclusive education and Universal Design for Learning is analysed. It has been established that the effectiveness of inclusive education is substantiated in practices which are based on real existing inclusive values: equity, equality, communality and respect for diversity. Based on the results of the study, it is concluded that the sustainability of inclusive education coincides with the real existence of inclusive values in practice, equally applying to all students.
\end{abstract}

Keywords: inclusive values, inclusion, integration, special needs education, Universal Design for Learning.

\section{Introduction}

The practice of inclusive education is forming in the contexts of historical, cultural and economic experiences and is based on values that prioritise unalienable human value. It is in the process of constant change and covers modifications in content, approaches, strategies and structures addressing the needs of children and adults (UNESCO, 2003). It gradually develops in educational policy and practice, following the general values that lead to a more just society (UNESCO, 2009). The Salamanca Statement and Framework for Action on Special Needs Education emphasise the value of inclusive education:

We believe and proclaim that: "regular schools with this inclusive orientation are the most effective means of combating discriminatory attitudes, creating welcoming communities, building an inclusive society and achieving education for all; moreover, they provide an effective education to the majority of children and improve the efficiency and ultimately the cost-effectiveness of the entire education system" (UNESCO, 1994, ix).

The research results of the European Agency for Special Needs and Inclusive Education (EASIE) (2019a) confirm the value of inclusive education. It is stated 
that the implementation of inclusive education can contribute to finding solutions to problems of failures at school and early dropout and enhance the achievement of all students if the school and national education system is based on the value of equity and inclusive practice.

The origins of inclusive values are linked to the fundamental values encompassed in the Universal Declaration on Human Rights (UN General Assembly, 1948), which affirms the prerogative of human rights and freedoms and of the principle of non-discrimination with respect to every human being, regardless of his or her 'race, colour, sex, language, religion, political or other opinion, national or social origin, property, birth or other status' (Article 2). The concept of discrimination is defined in the UN Convention Against Discrimination in Education as actions depriving of access to education of any type and at any level, limiting to education of an inferior standard, establishing or maintaining separate educational systems or institutions and inflicting conditions that are incompatible with the dignity of man on any person or group of persons (UN, 1960, Article 1).

Inclusive values derive from the above-mentioned world-level agreements and are specified by acknowledgement of equity, establishment of conditions for full participation, assurance of equal rights, creation of communal relations, respect for diversity, and sustainability (Ainscow, Booth, \& Dyson, 2006). Fundamental inclusive values and equity first permeate educational policy and management (Ainscow, 2020) and are reflected in the community goals, beliefs, attitudes, traditions and behaviour (Mitchell, 2015) and in child-centred teaching approaches and educational practice based on the wellbeing of all learners, selfdirected learning, and development of creative, emotional and cognitive powers (Mitchell, 2008).

Booth and Ainscow (2002) determine the concept of inclusive education through dimensions of culture, policy and practice. It concretises inclusive culture through the formation of the school community and the hierarchy of inclusive values; inclusive policies - the development of a school for all and the organisation of support for student diversity; and inclusive practice - the concept of orchestrative education and the accumulation of necessary educational tools. However, the understanding and implementation of inclusive principles differ in the structures of different countries due to political and economic development and cultural experience (Vislie, 2003; Magnússon, Göransson \& Lindqvist, 2019). The majority of school principals in European Union countries understand inclusive education as a narrow issue related to organising education for pupils with special educational needs (EASIE, 2019b).

The scientific and practical relevance of this study is to reveal the preconditions for the sustainability of effective inclusive education practices. Given that inclusion processes evolve under the influence of cultural, political and 
economic decisions, it is important to analyse the expression of inclusive values in different practices, as they can lead to social justice; collaborative, successoriented learning; and support for learners (Sorkos \& Hajisoteriou, 2020), as well as equal opportunities (Medina-García, Doña-Toledo \& Higueras-Rodríguez, 2020).

This study seeks to answer the question: How are the educational practices that have emerged in the development of society based on fundamental values, creating the preconditions for the sustainability of inclusive education?

\section{Method}

In order to answer the question, an analysis was conducted using the method of scholarly literature overview with an inductive approach (Harding, 2019). From the EBSCO and Google Scholar databases, 36 sources were selected for analysis according to these criteria: (a) analyses the construct of inclusive education approaches; (b) reveals experiences of applying inclusion in the context of societal development; and (c) substantiates the results of the inclusion practice.

Based on a theoretical analysis of inclusive values, the values chosen are acknowledgement of equity; establishment of conditions for full participation; assurance of equal rights; creation of communal relations; respect for diversity; and sustainability (Ainscow, Booth \& Dyson, 2006). It is assumed that the sustainability of inclusion practices is based on their effectiveness and their link to the universally recognised values of inclusive education.

Inclusion approaches formed in the historical development of society and current practice were selected for the analysis: integration; individualised inclusive education; and Universal Design for Learning. In the analysis of the selected literature, the components of the implementation of inclusive approaches are distinguished, reflecting the existence of inclusive values. Summaries are associated with results that reflect the effectiveness of inclusion.

\section{Expression of Inclusive Values in the Integration Approach}

The origins of inclusive education practice are related to the beginning of the phenomenon of integration and its development. The idea of integration actualises the principles of desegregation and normalisation with regard to marginalised groups (Winzer, 2007) and is frequently related to public movements for the implementation of rights of all people (Salend \& Garrick Duhaney, 2011). Political leadership and legitimate decisions that open up the possibility for legal actions are relevant for the beginning of integration processes.

In 1954, the Supreme Court of the United States of America declared education of Afro-American children and white children in separate schools to be 
a racial segregational practice and therefore a violation of constitution. This served as a strong impetus for African-American rights movements, which initiated educational integration (Frankenberg \& Lee, 2002; Bartz \& Kritsonis, 2019). Responding to pressure from the public and on the requests of parents, a six-year-old African-American girl, Ruby Bridges, began attending an all-white elementary school. The value of equity and non-discrimination on the grounds of race was put into practice physically, but community relations were still marked by deep segregational experiences. During the first year at that school, the girl underwent complete isolation within the pupil group, suffered from parents' protests, and witnessed the exclusion of her teacher in the teachers' community (Coles, 2010).

Striving for the integration of disabled children into local communities in Norway in the period from 1950 to 1960, special schools and special classes were established in various regions of the country. During that period, the number of disabled children attending schools in Norway increased from approximately 4,000 to 20,000 pupils. The process created conditions for implementing the right of disabled pupils to education. However, schools still remained closed institutions, which were poorly involved in the lives of local communities (Ogden, 2014).

The restoration of Lithuania's independence and liberation from the Soviet regime fostered a public movement for integration of the disabled in the country. This was particularly noticeable after the adoption of the Law on Education of Republic of Lithuania in 1991, which ensured the right of the disabled to learn in general education schools. Non-governmental organisations promoted the movement of disabled children from homes to schools and from special schools to general education institutions. From 1995 to 2002, the number of pupils with special educational needs (SEN) in Lithuanian general education increased by about $150 \%$ - i.e. from 19,643 to 49,989 pupils (Open Society Institute, 2005). However, the research shows that the integration of SEN pupils by physically transferring them into educational institutions grounded on the paradigm of traditional education triggered experiences of inner segregation. Teachers failed to maintain systemic and productive pedagogical interaction in the learning process with these pupils, personalise their educational goals, and create confidence-based interpersonal relations in the pupils' community (Kaffemanienè, 2005; Galkienè, 2017).

The integration processes for national minorities are the most frequently stimulated, with an aim of cultural contact or economic equality. In Norway, the indigenous nation of Sami has been involved in the processes of 'Norwegisation' for more than 100 years (Keskitalo \& Olsen, 2019). A large number of countries have been investing in efforts to integrate the Roma people into society to improve their economic status (Curcic, Miskovic, Plaut \& Ceobanu, 2014; Kostka, 2015). 
However, the research shows that in the case of externally stimulated cultural or economic integration, there is a move towards acculturation and assimilation, or the fight for protecting one's own identity is encouraged (Keskitalo \& Olsen, 2019; Magazzini, 2020).

The phenomenon of integration focuses on the implementation of the value of equity in regard to society groups that differ from the majority and encourages a transition of society to new cultural and educational equilibria. However, this approach highlights the limitations of full participation and the realisation of community values. The existence of these values requires the openness of the majority to be integrated as well as the desire of the minority to maintain relations with them (Berry, 1997), acknowledgement of significant differences between the minority and majority (Eriksen, 2007) and clear self-awareness of the majority in the process of integration, including the adoption of new values and preserving their own identity (Mačiulytè, 2012).

\section{Expression of Inclusive Values in the Approach of Individualised Inclusive Education}

In the practice of inclusive education, the emphasis is laid on planning for all, achievement assessment, active collaborative participation, and support accessible to all (Booth \& Ainscow, 2002). Organisation of inclusive education for SEN learners gives sense to the links of general and special education elements (Florian, 2019; Paju, Kajamaa, Pirttimaa, \& Kontu, 2021). In this way, the practice of differentiation and individualisation of the curriculum, its implementation (Griful-Freixenet et al., 2020; Padia \& Traxler, 2020) and valuebased priorities of inclusive education acquire importance. The results of research conducted by Florian and Black-Hawkins (2011) show that in the cases when teachers apply the approach of individualised inclusive education through differentiation of curriculum and providing support to certain pupils, experiences of inner segregation are formed that distinguish and stigmatise these pupils. According to Aas (2019), teachers who use differentiated instruction characteristic of traditional education experience a lack of time for lesson planning and implementation. During lessons they are not able to allocate time to coping with pupils' difficulties, which frequently occur because they apply the approach of traditional education. They then tend to withdraw from it, deciding that some lessons are not useful to certain pupils.

Experience in individualised inclusive education is linked to the theory of inclusive special education, which was elaborated by Hornby (2015). This theory acknowledges inclusive education as a value, but its practice is grounded on the paradigm of special education. The essential goal is education of SEN pupils in special or general education institutions in early childhood, preparing them for 
inclusive participation in public life when they graduate from school. Supporters of this theory advocate the education of SEN pupils by special education teachers, doubting the competence of teachers in general education to achieve this goal. Although the theory of inclusive special education is rarely mentioned in the scientific literature, it explains the construct of individualised inclusive education and its application in practice (Florian \& Black-Hawkins, 2011; Galkienè, 2017; EASIE, 2019b). In many cases, this practice does not create conditions for the equal participation of all students and the formation of community values.

\section{Expression of Inclusive Values in the Approach of Universal Design for Learning}

The system of traditional education focuses on average-ability learners and their homogenous groups, fails to respond to diverse needs and therefore is frequently characterised as discriminatory towards pupils with special needs (Meyer, Rose, \& Gordon, 2014). The approach of inclusive education referred to as Universal Design for Learning (UDL) acknowledges learners' diversity, which consists of pupils' intellectual and cognitive differences, as well as their various interests and learning styles (Hymel \& Katz, 2019; Lee, 2019; Van Boxtel \& Sugita, 2019). UDL aims for every learner's success, ensured through the practices of education differentiation and common learning (Swanson, Ficarra \& Chapin, 2020; Van Boxtel \& Sugita, 2019). Taking into consideration the peculiarities of three brain networks (affective networks, recognition networks, and strategic networks) and following Vygotsky's socio-cultural theory and idea of the zone of proximal development (Vygotsky, 1962; Vygotsky, 1978), pupils are given challenging but potentially surmountable assignments that take their interests into account and promote their thinking. Recognising the individual differences of all learners, there is a transition from satisfying the individual needs of learners to creating a barrier-free educational environment which is capable of meeting the individual needs of all pupils (Meyer, Rose \& Gordon, 2014). Thus, all learners are enabled to participate in common learning activity (Rose \& Strangman, 2007), and the teacher's competence of empowering differentiation becomes an essential criterion for the learner's success and the teacher's professionalism (Van Boxtel \& Sugita, 2019; Swanson, Ficarra \& Chapin, 2020). Elements of special support are naturally integrated into common educational activity. They are accessible to all, and support is provided to everyone, whenever it is needed. Teachers, specialists and learners, including those with SEN, join a collaborative learning community. According to Farmer et al. (2018), learners' personal narratives are formed in social relations, which, according to Nieminen and Pesonen (2020), are of utmost importance to pupils' engagement in learning activities. 
The analysis of this approach to education reveals the existence of clear inclusive values, such as respect for the diversity of all students, equity for all students, conditions for full participation, equal rights and community building, and the effectiveness of evidence-based practice outcomes. Therefore, it can be assumed that the sustainability of inclusive education requires the realisation of universally recognised inclusive values, not only for some but for all students.

\section{Conclusions}

In response to the research question of how the educational practices that have emerged in the development of society are based on fundamental values, creating the preconditions for the sustainability of inclusive education, an analysis of the results of research substantiating the effectiveness of inclusive practices was performed.

The results of this study reveal the basis of the sustainability of inclusive education in the processes of societal change, which coincides with the existence of universally recognised inclusive values in educational practice. The results of the study show that a practice constructed on the basis of the values defined by international agreements and concretised by Ainscow, Booth \& Dyson (2006) (equity, participation, equality, community, respect for diversity and sustainability) ensures full participation and quality education for all students.

Integration processes are dominated by the values of equity and equality. However, the practice of integration is more frequently implemented by external stimulation than by natural involvement in prepared and anticipating communities. Therefore, the value of the community is lost. This reveals that the following elements are essential for sustainability of inclusion: preparation of the community for changes and openness to acknowledge otherness to provide it with the right to exist, as desynchronisation of goals to be achieved and preparation for their implementation impede the sustainability of inclusive processes.

In the case of individualised inclusion, the existence of special education elements in the system of inclusive education realises the value of respect for diversity. However, the practice, when this value is applied to some learners, it neutralises the values of equity and equality and thus leads to segregation. Sustainability of inclusive education requires an organic link between elements of special and general education, creating a flexible educational practice that is accessible to all and allows full and successful participation in the process of education.

Application of Universal Design for Learning creates a flexible education environment for all learners and implements the values of full participation, equity and respect for diversity. The analysis of this approach reveals that sustainability of inclusive education requires elements of acknowledgement of individual 
differences of all learners, formation of a barrier-free educational environment, empowering differentiation and common learning experiences and collaboration.

The research results show that prerequisites for the sustainability of inclusive education lie in the close relationships of inclusive values and effective educational practices based on them. Therefore, favourable legal regulation and individual initiatives are not sufficient for the development of inclusive education and its sustainability. It is necessary to ensure that the values of inclusive education truly exist in educational practice and equally apply to all students.

\section{References}

Aas, H. K. (2019). Teachers talk on student needs: exploring how teacher beliefs challenge inclusive education in a Norwegian context. International Journal of Inclusive Education, 1-15. DOI: $10.1080 / 13603116.2019 .1698065$

Ainscow, M. (2020). Promoting inclusion and equity in education: lessons from international experiences. Nordic Journal of Studies in Educational Policy, 6(1), 7-16. DOI: https://doi.org/10.1080/20020317.2020.1729587

Ainscow, M., Booth, T., \& Dyson, A. (2006). Inclusion and the standards agenda: negotiating policy pressures in England. International journal of inclusive education, 10(4-5), 295308. DOI: https://doi.org/10.1080/20020317.2020.1729587

Bartz, D. E., \& Kritsonis, W. A. (2019). Racism, the White Power Structure, and the Tragic History of the Education of African American Children in the United States. Schooling, 10 (1), p. 1-9.

Berry, J. W. (1997). Immigration, Acculturation, and Adaptation. Applied Psychology. An International Review, 46(1), 5-34.

Booth, T., \& Ainscow, M. (2002). Index for Inclusion: Developing Learning and Participation in Schools. Centre for Studies on Inclusive Education (CSIE).

Coles, R. (2010). The Story of Ruby Bridges. Scholastic Inc.

Curcic, S., Miskovic, M., Plaut, Sh., \& Ceobanu, C. (2014). Inclusion, Integration or Perpetual Exclusion? a Critical Examination of the Decade of Roma Inclusion, 2005-2015. European Educational Research Journal, 13(3), 257-267. DOI: http://doi.org/10.2304/ eerj.2014.13.3.257

EASIE. (2019a). Preventing School Failure: Examining the Potential of Inclusive Education Policies at System and Individual Levels. (A. Kefallinou, ed.). Odense, Denmark. Retrieved from: https://www.european-agency.org/sites/default/files/psf_project_ synthesis_report_pdf

EASIE. (2019b). Inclusive School Leadership: Exploring Policies Across Europe. (E. Óskarsdóttir, V. Donnelly and M. Turner-Cmuchal, eds.). Odense, Denmark. Retrieved from: https://www.european-agency.org/sites/default/files/sisl_synthesis_report.pdf

Eriksen, H.T. (2007). Complexity in social and cultural integration: Some analytical dimensions. Ethnic and Racial Studies, 30(6), 1055-1069. DOI: https://doi.org/10.1080/ 01419870701599481

Farmer, T.W., Dawes, M., Hamm, J.W., Lee, D., Mehtaji, M., Hoffman, A.,S., \& Brooks, D.S. (2018). Classroom Social Dynamics Management: Why the Invisible Hand of the Teacher Matters for Special Education. Remedial and Special Education, 39(3), 177-192. DOI: https://doi.org/10.1177/0741932517718359 
Florian, L. \& Black-Hawkins, K. (2011). Exploring inclusive pedagogy. British Educational Research Journal, 37(5), 813-828. DOI: https://doi.org/10.1080/01411926.2010.501096

Florian, L. (2019). On the Necessary Co-existence of Special and Inclusive Education. International Journal of Inclusive Education, 23(7-8), 691-704. DOI: http://doi:10.1080/13603116.2019.1622801

Frankenberg, E., \& Lee, Ch. (2002). Race in American Public Schools: Rapidly Resegregating School Districts. Harvard Civil Rights Project, Cambridge, MA. Retrieved from: https://files.eric.ed.gov/fulltext/ED468063.pdf

Galkienè, A. (2017). A necessary upgrade of inclusive education: experiences of Lithuanian teachers and parents of students experiencing educational failure. In D. JakavonyteStaškuviene \& E. Sakadolskis (Eds.), Towards Research-Based Education (528-563). The publishing house of the Lithuanian University of Educational Science. Retrieved from: https://www.researchgate.net/publication/322256129_A_NECESSARY_UPGRA DE_OF_INCLUSIVE_EDUCATION_EXPERIENCES_OF_LITHUANIAN_TEACHE RS_AND_PARENTS_OF_STUDENTS_EXPERIENCING_EDUCATIONAL_FAILU RE_P_546-563

Griful-Freixenet, J., Struyven, K., Vantieghem, W., \& Gheyssens, E. (2020). Exploring the interrelationship between Universal Design for Learning (UDL) and Differentiated Instruction (DI): A systematic review. Educational Research Review, 29. DOI: https://doi.org/10.1016/j.edurev.2019.100306

Harding, J. (2019). Qualitative Data Analysis. From Start to Finish. SAGE Publications.

Hymel, S., \& Katz, J. (2019). Designing classrooms for diversity: Fostering social inclusion. Educational Psychologist, 54(4), 331-339. DOI: https://doi.org/10.1080/00461520. 2019.1652098

Hornby, G. (2015). Inclusive Special Education: Development of a New Theory for the Education of Children with Special Educational Needs and Disabilities. British Journal of Special Education, 42(3), 234-256. DOI: https://doi.org/10.1111/1467-8578.12101

Kaffemanienè, I. (2005). Pedagoginès sąveikos struktūra ugdant mokymosi negalių turinčius moksleivius bendrojo lavinimo klaseje [Structure of pedagogical interaction when educating pupils with learning disabilities in general classrooms]. Specialusis ugdymas / Special education, (1), 85-101.

Keskitalo, P. \& Olsen, T. (2019). Historical and Political Perspectives on Sámi and Inclusive School Systems in Norway. In M. C. Beaton, D. B. Hirshberg, G. R. Maxwell, J. Spratt (Eds.), Including the North: a Comparative Study of the Policies on Inclusion and Equity in the Circumpolar North (pp. 109 - 123). Arctic Council. SAOFI204_2019_RUKA_0701-01_SDWG_Book-Including-the-North. Retrieved from: http://hdl.handle.net/ $11374 / 2288$

Kostka, J. (2015). Implementation of Roma Inclusion Policies: Why Defining the Problem Matters. Social Inclusion, 3(5), 78-89. DOI: http://dx.doi.org/10.17645/si.v3i5.231

Lee, B. P. (2019). UDL: A Primer for Community College CTE Instruction. CTE Journal, 7(2). Retrieved from: https://www.thectejournal.com/uploads/1/0/6/8/10686931/lee_fall_ 2019.pdf

Mačiulyte, J. (2012). Lithuanians in Norway: between conservation and integration. OIKOS: Lietuvių migracijos ir diasporos studijos, 23-42. Retrieved from: https://etalpykla.lituanistikadb.lt/fedora/objects/LT-LDB-

0001:J.04 2012 1368043447500/datastreams/DS.002.1.01.ARTIC/content

Magazzini, T. (2020). Integration as an Essentially Contested Concept: Questioning the Assumptions Behind the National Roma Integration Strategies of Italy and Spain. In S. 
Hinger, \& R. Schweitzer (Eds.), Politics of (Dis) Integration (pp. 41-59). Springer Open. DOI: https://doi.org/10.1007/978-3-030-25089-8

Magnússon, G., Göransson, K., \& Lindqvist, G. (2019). Contextualizing inclusive education in educational policy: the case of Sweden. Nordic Journal of Studies in Educational Policy, 5(2), 67-77. DOI: https://doi.org/10.1080/20020317.2019.1586512

Medina-García, M., Doña-Toledo, L., \& Higueras-Rodríguez, L. (2020). Equal Opportunities in an Inclusive and Sustainable Education System: An Explanatory Model. Sustainability, 12(11), 4626. DOI: https://doi.org/10.3390/su12114626

Meyer, A., Rose, D. H. \& Gordon, D. (2014). Universal design for learning: Theory and practice. CAST Professional Publishing.

Mitchell, D. (2008). What really works in special and inclusive education: Using evidencebased teaching strategies. Routledge.

Mitchell, D. (2015). Inclusive education is a multi-faceted concept. Center for Educational Policy Studies Journal, 5(1), 9-30.

Nieminen, J.H., \& Pesonen, H.V. (2020). Taking Universal Design Back to Its Roots: Perspectives on Accessibility and Identity in Undergraduate Mathematics. Education Sciences, 10(1), 12. DOI: 10.3390/educsci10010012

Ogden, T. (2014). Special Needs Education in Norway-the Past, Present, and Future of the Field. In The Past, the Present and the Future of Special Education: Advances in Learning and Behavioral Disabilities (213-238). Emerald Group Publishing Limited. DOI: https://doi.org/10.1108/S0735-004X20140000027012

Open Society Institute. (2005). Rights of People with Intellectuoal Disabilities. Access to Education and Employment. Monitoring Report. Retrieved from: https://www.open societyfoundations.org/publications/rights-people-intellectual-disabilities-accesseducation-and-employment

Padia, L., \& Traxler, R.E. (2020). (Special) Education is Political;(Special) Education is Social Justice. Journal of Critical Thought and Praxis, 10(1). DOI: https://doi.org/10.31274/ jctp.11613

Paju, B., Kajamaa, A., Pirttimaa, R., \& Kontu, E. (2021). Collaboration for Inclusive Practices: Teaching Staff Perspectives from Finland. Scandinavian Journal of Educational Research, 1-14. DOI: https://doi.org/10.1080/00313831.2020.1869087

Rose, D. H., \& Strangman, N. (2007). Universal design for learning: Meeting the challenge of individual learning differences through a neurocognitive perspective. Universal Access in the Information Society, 5(4), 381-391. DOI: 10.1007/s10209-006-0062-8

Salend, S.J., \& Garrick Duhaney, L.M. (2011). Historical and philosophical changes in the education of students with exceptionalities. In A. F. Rotatori, F. E. Obiakor, \& J. P. Bakken, (Eds.) History of Special Education, Vol. 21 (1-20). Emerald Group Publishing Limited, Bingley. DOI: https://doi.org/10.1108/S0270-4013(2011)0000021004

Sorkos, G., \& Hajisoteriou, C. (2020). Sustainable intercultural and inclusive education: teachers' efforts on promoting a combining paradigm. Pedagogy, Culture \& Society, 1(20). DOI: https://doi.org/10.1080/14681366.2020.1765193

Swanson, J. A., Ficarra, L. R., \& Chapin, D. (2020). Strategies to strengthen differentiation within the common core era: drawing on the expertise from those in the field. Preventing School Failure: Alternative Education for Children and Youth, 64(2), 116-127. DOI: https://doi.org/10.1080/1045988X.2019.1683802

UN General Assembly. (1948). Universal Declaration of Human Rights, 10 December 1948, 217 A (III). Retrieved from: https://www.refworld.org/docid/3ae6b3712c.html 
Proceedings of the International Scientific Conference. Volume II, May $28^{\text {th }}-29^{\text {th }}, 2021.192-202$

UN. (1960). Convention against Discrimination in Education. Paris. Retrieved from: http://portal.unesco.org/en/ev.php-

URL_ID=12949\&URL_DO=DO_TOPIC\&URL_SECTION=201.html

UNESCO. (1994). The Salamanca Statement and Framework for Action on Special Needs Education. Retrieved from: https://www.european-agency.org/sites/default/files/ salamanca-statement-and-framework.pdf

UNESCO. (2003). Overcoming Exclusion through Inclusive Approaches in Education. A challenge and a vision. Paris. Retrieved from: https://unesdoc.unesco.org/ ark:/48223/pf0000134785

UNESCO. (2009). Policy Guidelines on Inclusion in Education. Paris. Retrieved from: https://unesdoc.unesco.org/ark:/48223/pf0000177849

Van Boxtel, J. M., \& Sugita, T. (2019). Exploring the Implementation of Lesson-level UDL Principles through an Observation Protocol. International Journal of Inclusive Education, 1-17. DOI: https://doi.org/10.1080/13603116.2019.1655596

Vygotsky, L. S. (1962). Thought and Language. Cambridge, MA, MIT Press.

Vygotsky, L. S. (1978). Mind in Society. London: Harvard University Press.

Vislie, L. (2003). From integration to inclusion: focusing global trends and changes in the western European societies. European journal of special needs education, 18(1), 17-35.

Winzer, M. A. (2007). Confronting Difference: An Excursion Through the History of Special Education. In L. Florian (Ed), The SAGE Handbook of Special Education (21-33). SAGE Publications Ltd. 